\title{
Analisis Keberlanjutan dan Pola Pengembangan Co-Operative Entrepreneurship Lembaga Keuangan Mikro Agribisnis (LKM-A)
}

\author{
Ratih Apri Utami
}

\begin{abstract}
In 2008 the government implement the program of Rural Agribusiness Development (PUAP) are routed through Gapoktan of 100 million dollars. PUAP fund intended as a stimulus that can be grown into Agribussiness Microfinance Institutions (LKM-A) for the sustainable financing for farmers. The purpose of this study was to analyze the sustainability of LKM-A of Gapoktan Sejahtera at Lamongan based approach to institutional, financial and customers, and to develop approaches needed LKM-A towards the Co-operative Entrepreneurship. The results showed that the LKM-A Gapoktan Sejahtera is own institutional sustainability through the management of the organization and financing schemes during one growing season, financial sustainability is based on the interest rate / loan unit is greater than the burden of financing and sustainability customers through customer perception regarding the distribution, utilization and refund PUAP. LKM-A development pattern towards the Co-operative Entrepreneurship through curriculum materials group to the central actors that chairman of Gapoktan, chairman of the LKM-A, and the Chairman of farmer groups to attend the field school which consists of training and apprenticeship. The material is arranged adjusted potential of the village and Agricultural Information System which was developed through a partnership the Ministry of Agriculture, Department of Agriculture and the College of Agriculture.
\end{abstract}

\section{Keywords:}

Gapoktan; PUAP; LKM-A; sustainability; co-operative entrepreneurship.

\begin{abstract}
Abstrak
Pada tahun 2008 pemerintah melaksanakan program Pengembangan Usaha Agribisnis Perdesaan (PUAP) yang disalurkan melalui Gapoktan sebesar 100 juta rupiah. Dana PUAP bertujuan sebagai stimulus agar dapat ditumbuhkan menjadi Lembaga Keuangan Mikro Agribisnis (LKM-A) untuk keberlanjutan pembiayaan untuk petani. Tujuan penelitian ini adalah untuk menganalisis proses penumbuhan LKM-A dan keberlanjutan LKM-A berdasarkan pendekatan kelembagaan, finansial dan nasabah, serta mengembangkan pendekatan yang dibutuhkan LKM-A menuju Co-operative Entrepreneurship. Hasil penelitian menunjukkan bahwa LKM-A Gapoktan Sejahtera sudah memiliki keberlanjutan kelembagaan melalui manajemen organisasi dan skema pembiayaan selama satu musim tanam, keberlanjutan finansial didasarkan pada tingkat bunga/unit pinjaman lebih besar dari beban pembiayaan dan keberlanjutan nasabah melalui persepsi nasabah mengenai penyaluran, pemanfaatan dan pengembalian dana PUAP (Pengembangan Usaha Agribisnis Perdesaan). Pola pengembangan LKM-A menuju Co-operative Entrepreneurship diawali melalui proses penumbuhan LKM-A, analisis keberlanjutan berdasarkan pendekatan lembaga, finansial,
\end{abstract}

\footnotetext{
- Mahasiswa Magister Sains Agribisnis (MSA), Fakultas Ekonomi dan Manajemen, Sekolah Pascasarjana IPB. Email: ratihapri17@gmail.com
} 
nasabah untuk kemudian dikembangkan pola materi kurikulum kelompok kepada pelaku sentral yaitu Ketua Gapoktan, ketua LKM-A, dan Ketua kelompok Tani untuk mengikuti sekolah lapang yang terdiri dari pelatihan dan magang. Materi yang disusun disesuaikan potensi desa dan Sistem Informasi Pertanian yang disusun melalui kerjasama Kementerian Pertanian, Dinas Pertanian Kabupaten dan Perguruan Tinggi.

\section{Kata Kunci:}

Gapoktan; PUAP; LKM-A; keberlanjutan; co-operative entrepreneurship.

\section{Pendahuluan}

Sektor pertanian dan agribisnis di perdesaan merupakan sumber pertumbuhan perekonomian nasional. Agribisnis perdesaan berkembang melalui partisipasi aktif petani melalui sistem komunitas dan kelembagaan. Saragih (2015), menyatakan bahwa petani di perdesaan umumnya berskala usaha kecil-kecil tapi jumlahnya banyak. Petani-petani kecil sering tidak mampu menangkap skala usaha ekonomis di bidang produksi, distribusi, dan mendapatkan layanan jasa. Inilah yang menjadi alasan ekonomis pentingnya suatu organisasi ekonomi petani. Kebijakan pengembangan kelembagaan tani berbasis 1 (satu) Gabungan Kelompok Tani (Gapoktan) dalam 1 (satu) desa, merupakan upaya Kementerian Pertanian untuk membangun organisasi tani yang kuat, mandiri sebagai basis pertumbuhan ekonomi yang diharapkan dapat meningkatkan kinerja ekonomi petani di perdesaan.

Inovasi kelembagaan melalui kelompok tani memerlukan fasilitas permodalan yang bisa diakses oleh petani dengan mudah. Di sisi lain untuk mendapatkan modal dengan mengandalkan lembaga keuangan formal yang ada, terkendala persyaratan administrasi yang tidak dapat memenuhinya. Untukmendapatkan modal atau kredit dari lembaga keuangan formal (perbankan), petani dihadapkan pada persyaratan formal administrasi dan kesulitan akses permodalan.

Belajar dari pengalaman kredit program atau bantuan modal dari pemerintah, ternyata sebagian besar program tidak dapat berkelanjutan pelaksanaannya di tingkat lapang. Setelah program selesai, petani tidak lantas menjadi mandiri dan sejahtera. Salah satu penyebabnya adalah karena dana bantuan program pemerintah tidak dapat dikelola dengan baik oleh petani. Pada tahun 2008, Kementerian Pertanian melaksanakan Program Pengembangan Usaha Agribisnis Perdesaan (PUAP) sebagai program prioritas yang dilaksanakan secara terintegrasi dengan kegiatan Kementerian atau Lembaga lain di bawah payung Program Nasional Pemberdayaan Masyarakat (PNPM) Mandiri. PUAP dirancang secara partisipatif dengan petani, kelompok tani, dan gabungan kelompok tani (Gapoktan) sebagai pelaku utama yang difasilitasi oleh pemerintah dari tingkat Kementerian Pertanian sampai ke desa atau kelurahan.

Kelembagaan tani pelaksana program PUAP yang berfungsi sebagai pengelola bantuan modal usaha bagi petani anggota adalah Gapoktan Pengelolaan bantuan program PUAP melalui Gapoktan dengan harapan dana tersebut dapat tumbuh dan berkembang, melalui unit usaha otonom simpan pinjam atau Lembaga Keuangan Mikro Agribisnis (LKM-A). Pola LKM-A ini sejalan dengan kebijakan revitalisasi pertanian dan rencana strategis pembangunan pertanian yang mengarahkan upaya pengelolaan keuangan seiring dengan peningkatan kapasitas kelompok tani.

Pendistribusian dana PUAP Kementerian Pertanian didasarkan pada jumlah desa pertanian yang menunjang swasembada padi, jagung, dan kedelai (pajale). Padi, jagung, dan kedelai merupakan komoditas unggulan dalam rangka 
mewujudkan ketahanan pangan Indonesia. Berdasarkan data Badan Pusat Statistik (2014), provinsi dengan luas panen terbesar tanaman pangan pajale disajikan pada tabel 1 .

Provinsi Jawa Timur merupakan provinsi dengan luas panen terbesar untuk tanaman padi, jagung, dan kedelai. Salah satu kabupaten di provinsi Jawa Timur yang mendapatkan PUAP terbanyak sejak tahun 2008 adalah Kabupaten Lamongan.

Dana penguatan modal usaha PUAP secara terstruktur digulirkan Gapoktan kepada para anggota kelompok tani sebagai peminjaman sehingga pada Tahun ke-2 Gapoktan sudah dapat mengembangkan Unit Usaha Simpan Pinjam (U-S/P). Gapoktan penerima bantuan BLM-PUAP diharapkan dapat menjaga perguliran dana sampai pada fase pertumbuhan Lembaga Keuangan Mikro Agribisnis (LKM-A) pada Tahun ke-3. Perkembangan Gapoktan penerima dana PUAP Kabupaten Lamongan, Provinsi Jawa Timur dan Nasional yang telah membentuk LKM-A tahun 2008-2013 dapat dilihat pada tabel 3.

Tabel 1.

Luas panen tanaman padi, jagung, dan kedelai provinsi di Indonesia

\begin{tabular}{crccc}
\hline \multirow{2}{*}{ No. } & \multirow{2}{*}{ Provinsi } & \multicolumn{3}{c}{ Luas panen $(\mathrm{Ha})$} \\
\cline { 3 - 5 } & & Padi & Jagung & Kedelai \\
\hline 1 & Jawa Timur & 2.072 .822 & 1.202 .300 & 214.880 \\
2 & Jawa Tengah & 1.800 .908 & 538.102 & 72.235 \\
3 & Jawa Barat & 1.979 .799 & 142.964 & 70.719 \\
4 & Sulawesi Selatan & 1.042 .192 & 291.111 & 36.326 \\
5 & Lampung & 648.451 & 338.886 & 11.355 \\
\hline
\end{tabular}

Sumber: Badan Pusat Statistik (2014)

Tabel 2.

Jumlah Gapoktan penerima dana PUAP Kabupaten Lamongan, Provinsi Jawa Timur, dan Nasional tahun 2008-2013

\begin{tabular}{lcccccc}
\hline \multicolumn{1}{c}{ Tingkat } & \multicolumn{5}{c}{ Jumlah Gapoktan Penerima PUAP } \\
\cline { 2 - 7 } & 2008 & 2009 & 2010 & 2011 & 2012 & 2013 \\
\hline Nasional & 10542 & 9884 & 8587 & 9110 & 6050 & 3300 \\
Provinsi Jawa Timur & 1083 & 925 & 906 & 1243 & 954 & 426 \\
Kabupaten Lamongan & 35 & 17 & 92 & 83 & 45 & 42 \\
\hline
\end{tabular}

Sumber: Kementerian Pertanian (2014)

Tabel 3.

Jumlah LKM-A Kabupaten Lamongan, Provinsi Jawa Timur, dan Nasional Tahun 2008-2013

\begin{tabular}{lccc}
\hline \multirow{1}{*}{ Tingkat } & $\begin{array}{c}\text { Jumlah Gapoktan } \\
\text { Penerima PUAP }\end{array}$ & $\begin{array}{c}\text { Jumlah Gapoktan yang } \\
\text { Telah Membentuk } \\
\text { LKM-A }\end{array}$ & Persentase (\%) \\
\hline Nasional & 14395 & 3354 & 23.30 \\
Provinsi Jawa Timur & 1220 & 207 & 16.97 \\
Kabupaten Lamongan & 314 & 29 & 9.24 \\
\hline
\end{tabular}

Sumber: Kementerian Pertanian (2014) 
Salah satu LKM-A yang berada di Kabupaten Lamongan adalah LKM-ASejahtera. Berdasarkan evaluasi yang dilakukan oleh Dinas Pertanian dan Kehutanan Kabupaten Lamongan, menyebutkan bahwa LKM-A Sejahtera menjadi LKM-A terbaik se-Kabupaten Lamongan pada tahun 2013. Keberadaan LKM-A Sejahtera penerima dana PUAP di Kabupaten Lamongan dari tahun 2011 hingga saat ini adalah salah satu upaya untuk mewujudkan alternatif solusi permodalan bagi para petani dalam mengembangkan usaha agribisnis perdesaan.

\section{Metode Penelitian}

Pemilihan lokasi pengambilan data dilakukan secara purposive. Daerah yang dipilih sebagai tempat penelitian dilakukan di LKM-A Sejahtera, Kabupaten Lamongan. Pemilihan tempat penelitian tersebut karena LKM-A merupakan rekomendasi dari pihak Dinas Pertanian dan Kehutanan Kabupaten Lamongan sebagai LKM-A yang berprestasi tahun 2013. Pengambilan data penelitian dilakukan pada bulan Februari dan Maret 2015.

Data yang digunakan dalam penelitian ini terdiri dari data primer dan data sekunder. Data primer diperoleh dari hasil pengisian kuesioner dan wawancara langsung dengan responden yaitu pejabat Kementerian Pertanian, pejabat Dinas Pertanian dan Kehutanan, Penyelia Mitra Tani (PMT), Dosen akademisi Perguruan Tinggi, pengurus dan petani anggota LKM-A. Data sekunder diperoleh dari Direktorat Pembiayaan Pertanian Kementerian Pertanian (berupa Pedoman Pengembangan LKM-A, Pedoman Pemeringkatan Gapoktan PUAP dan jumlah Gapoktan penerima PUAP Nasional tahun 2008-2014), Dinas Pertanian dan Kehutanan Kabupaten Lamongan (berupa pedoman pendampingan LKM-A dan jumlah Gapoktan Kabupaten Lamongan penerima PUAP tahun 2008-2014), Unit Pelaksana Teknis Pertanian dan Kehutanan Kabupaten Lamongan (berupa data pendamping dan anggota Kelompok Tani), selain itu data sekunder juga diperoleh dari penelusuran kepustakaan, internet dan literatur lain yang berhubungan dengan penelitian ini.

Pendekatan deskriptif dilakukan untuk menganalisis proses penumbuhan LKM-A pada Gapoktan PUAP. Pemberian bobot nilai untuk keperluan analisis proses penumbuhan LKM-A menggunakan skala Likert ( $5=$ sangat baik, 4= baik, 3= cukup baik, 2= kurang baik, dan $1=$ buruk). Analisis kuantitatif dilakukan untuk melihat kinerja keberlanjutan melalui tiga pendekatan (finansial, kelembagaan dan anggota) sebagai alternatif lembaga permodalan agribisnis perdesaan. Sedangkan analisis kualitatif digunakan sebagai pendekatan untuk implikasi pola pengembangan LKM-A berbasis Co-operative Entrepreneurship. Pengolahan data dilakukan dengan menggunakan Microsoft Excel 2007.

\section{Analisis Keberlanjutan LKM-A}

Berdasarkan pemikiran Khandker, Khaliliy, dan Khan (1995) yang diaplikasikan oleh Syukur (2002), bahwa keberlanjutan lembaga berkaitan dengan tiga hal, yaitu:

\section{a. Viabilitas Finansial}

Perhitungan viabilitas finansial pada lembaga perkreditan adalah suatu kondisi di mana suatu skim kredit dapat menutupi seluruh biaya operasional dari pendapatan yang diperoleh (bunga) yang dibayar oleh peminjam (peserta) (Khandker, et. al. 1995).

Apabila,

$\mathrm{r}=$ tingkat bunga/unit pinjaman

$\mathrm{I}$ = biaya untuk mendapatkan pokok pinjaman

$\alpha=$ biaya administrasi dan supervise

$\mathrm{L}=$ finansial loss/unit pinjaman

$\mathrm{X}=$ jumlah pinjaman yang disalurkan (loan portfolio)

Maka viabilitas finansial dapat dicapai bila memenuhi persyaratan, 
$r \geq \frac{(i+\alpha+L}{(1-L)}$

\section{b. Viabilitas Kelembagaan}

Untuk menjamin agar suatu lembaga keuangan dapat viable secara institusi, maka lembaga keuangan tersebut haruslah memiliki prosedur atau mekanisme delivery system yang telah melembaga yang dapat menjamin berlangsungnya keberhasilan manajemen dan administrasi, dan tidak bergantung pada figur personal tertentu dalam mengelola lembaga keuangan tersebut. Analisis kelembagaan suatu lembaga keuangan dapat dilakukan menggunakan pendekatan masalah utama, yaitu screening, incentive dan enforcement. Analisis dilakukan secara deskriptif terhadap ketiga persoalan tersebut.

\section{c. Perspektif Anggota}

Keberlanjutan anggota LKM-A Gapoktan Sejahtera menggunakan persepsi nasabah petani sebagai anggota. Analisis persepsi anggota petani disesuaikan dengan tujuan program PUAP dan indikator keberhasilan pengelolaan dana PUAP oleh LKM-A dalam kemampuannya menjangkau anggota kelompok tani yang benar-benar memerlukan bantuan penguatan modal untuk kegiatan usahatani. Persepsi petani yang dianalisis dibagi dalam tiga instrumen kelompok, yaitu 1) persepsi anggota petani terhadap penyaluran dana PUAP, 2) persepsi anggota petani terhadap pemanfaatan dana PUAP, dan 3) persepsi anggota petani terhadap pengembalian dana PUAP. Skor penilaian menggunakan skala Likert 1-5 (1= sangat tidak penting, $2=$ tidak penting, $3=$ cukup penting, $4=$ penting, $5=$ sangat penting).

\section{Proses Penumbuhan LKM-A Gapoktan Sejahtera}

Untuk mempermudah analisis proses penumbuhan LKM-A, penulis melakukan inventarisasi terhadap variabel-variabel yang disajikan dalam tabel dengan memberikan nilai bobot menggunakan skala Likert. Untuk tahapan nomor 1 dan 3, pembobotan nilai kuesioner menggunakan skala Likert (sangat baik, baik, cukup baik, kurang baik, dan buruk dengan bobot nilai masing-masing secara berturut-turut 5, 4, 3, 2, 1 . Tahapan nomor 2 juga menggunakan skala Likert (sangat ringan, ringan, cukup berat, berat, sangat berat) dengan bobot nilai yang sama. Sedangkan untuk tahapan nomor $4-7$ pembobotan nilai kuesioner menggunakan skala Biner, di mana nilai 1 untuk ada atau dilaksanakan, dan 0 untuk tidak/belum ada atau tidak dilaksanakan. Responden yang mengisi kuesioner pada proses penumbuhan LKM-A Gapoktan Sejahtera ialah stakeholders yang memiliki wewenang dalam penumbuhan LKM-A di Kabupaten Lamongan, Tim Pembina Kabupaten (Dinas Pertanian Kabupaten Lamongan), Penyelia Mitra Tani (PMT) dan Petugas Penyuluh Lapang (PPL). Hasil proses penumbuhan LKM-A terhadap Gapoktan Sejahtera di Kabupaten Lamongan tahun PUAP 2011 sampai 2013 disajikan pada Tabel 4.

Berdasarkan data yang dikumpulkan, hasil penumbuhan LKM-A terhadap Gapoktan Sejahtera penerima PUAP di Kabupaten Lamongan, pada tahap pemeringkatan hingga tahap persiapan pembentukan LKM-ASejahtera, secara umum berjalan "cukup baik". Hal itu dapat dilihat dari nilai indikator penumbuhan ke-1 sampai dengan ke-3 yang memiliki nilai rata-rata di atas 3, dan nilai indikator $\mathrm{ke}-4$ yang hampir mendekati angka 1. Artinya, beberapa aktivitas yang harus dilakukan dan beberapa persyaratan yang harus dipenuhi oleh Gapoktan Sejahtera untuk membentuk LKM-A, dilaksanakan dengan cukup baik. Namun, ketika memasuki tahap pelaksanaan yang diwakili oleh indikator ke-5 sampai dengan ke-7, LKM-A Gapoktan Sejahtera tidak mampu memenuhi persyaratan yang harus diselesaikan. Hal itu dapat dilihat dari rendahnya nilai ratarata pemenuhan persyaratan administrasi 
Tabel 4 .

Hasil penumbuhan LKM-A Gapoktan Sejahtera

Kabupaten Lamongan

\begin{tabular}{clc}
\hline No & Parameter Proses Penumbuhan LKM-A & Rata-Rata Nilai \\
\hline 1 & Pemeringkatan Gapoktan menjadi LKM-A (A) & 3.6 \\
2 & Hambatan Pengembangan LKM-A (B) & 3.1 \\
3 & Upaya mengatasi hambatan (C) & 3.3 \\
4 & Tahap persiapan pembentukan LKM-A (D) & 0.8 \\
5 & Persyaratan administrasi LKM-A (E) & 0.5 \\
6 & Tahap pelaksanaan LKM-A (F) & 0.5 \\
7 & Tahap pengembangan usaha LKM-A (G) & 0.4 \\
\hline
\end{tabular}

Sumber: Data Primer, 2015(diolah)

Keterangan:

Nomor 1 sampai 3; bobot nilai menggunakan skala Likert (5=sangat baik, 4=baik, $3=$ cukup baik, 2=kurang baik, 1=buruk).

Nomor 4 sampai 7; bobot nilai menggunakan skala Biner (1=ada/dilaksanakan, $0=$ tidak ada/belum dilaksanakan)

LKM-A (0.5); nilai rata-rata pelaksanaan atau operasional LKM-A (0.5); dan nilai rata-rata tahap pengembangan usaha LKM-A (0.4). Itu berarti, pengelola LKM-A hanya memiliki semangat dan keseriusan ketika hendak pembentukan LKM-A saja, tetapi ketika pada fase pelaksanaan dan pengembangan LKM-A, semangat untuk mengembangkan LKM-A menurun.

\section{Analisis Keberlanjutan LKM-A Gapoktan Sejahtera}

1. Keberlanjutan Kelembagaan

a. Prosedur dan Mekanisme Pembiayaan pada LKM-A Gapoktan Sejahtera

Prosedur dan mekanisme yang dijalankan LKM-A Gapoktan Sejahtera memiliki sistem pembiayaan usahatani metode kelompok selama satu musim tanam (gambar 1). Skema penyaluran digambarkan pada garis panah tebal dimulai dari penyaluran dana PUAP 100 juta dari Kementerian Pertanian melalui Gapoktan Sejahtera hingga pembentukan LKM-A. Besaran penyaluran dana PUAP kepada kelompok didasarkan pada jumlah anggota dan kebutuhan petani di masingmasing kelompok. Petani melalui kelompok tani akan mengajukan besarnya pinjaman sesuai dengan kebutuhan dan kelayakan petani peminjam. Selanjutnya dana PUAP akan disalurkan kepada petani secara bergilir. Sedangkan untuk besarnya jasa pinjaman ditentukan 1.5 persen.

Skema pengembalian ditunjukkan oleh garis panah patah-patah. Nasabah atau anggota akan mengembalikan biaya peminjaman garap melalui ketua kelompok tani. Jasa pinjaman 1.5 persen ini akan dikembalikan untuk kegiatan Gapoktan sendiri. Dengan pembagian Jasa 1 persen untuk penguatan modal (0.4 persen), kas gapoktan (0.3 persen) dan operasionalisasi LKM-A(0.3 persen). Sedangkan sisanya sebesar 0.5 persen digunakan untuk operasional tujuh kelompok tani Gapoktan Sejahtera.

\section{b. Manajemen Organisasi Pembiayaan}

Jika dilihat dari struktur organisasi, LKM-A Gapoktan Sejahtera masih menerapkan struktur sederhana sesuai kebutuhan awal, yaitu Ketua, Sekretaris dan Bendahara. Hubungan pembentukan struktur organisasi lebih demokratis melalui pemilihan rapat anggota sehingga kepercayaan atas dasar anggota kelompok sendiri lebih besar. Berdasarkan pola manajemen organisasi LKM-A Gapoktan Sejahtera, maka dapat disimpulkan bahwa 
pengelolaan pembiayaan tidak bergantung pada figur personal tertentu, melainkan dapat dilakukan secara kolektif koordinatif melalui pengurus Tim Pembina Kabupaten, PMT, PPL, pengurus LKM-A, Ketua Kelompok Tani dan anggota.

Sedangkan berkaitan dengan aturan main, keberlanjutan kelembagaan menyangkut kriteria seleksi (screening), sistem insentif (incentive) dan persoalan yang berkaitan dengan enforcement. Kriteria yang dipakai pada tahap screening LKM-A Gapoktan Sejahtera diantaranya adalah sumber penghasilan usahatani untuk mengetahui kemampuan membayar kembali pinjaman, karakter calon peminjam, luas lahan dan kebutuhan pembiayaan untuk satu musim tanam. Screening dilakukan oleh Ketua kelompok tani yang lebih memahami kriteria calon peminjam untuk diajukan melalui daftar kepada pengurus LKM-A Gapoktan Sejahtera. Incentive yang diterapkan LKM-A Gapoktan Sejahtera adalah: (a). Pinjaman dikembalikan selama satu musim tanam (6 bulan) dengan periode bulan OktoberMaret dan April-September. (b). Persyaratan pengajuan yang mudah tanpa menggunakan jaminan dengan bunga yang rendah 1.5 persen. (c). Seluruh proses pengembalian pinjaman dilakukan dalam pertemuan Rapat Anggota yang disaksikan oleh pengurus LKM-A dengan dipandu dan diawasi oleh PPL dan PMT. Sedangkan Enforcement pada LKM-A Gapoktan Sejahtera diantaranya: (a). Pengembalian dilakukan melalui kelompok tani yang disebut tanggung renteng, artinya apabila nasabah petani belum mampu mengembalikan maka sementara akan ditanggung kelompok sampai bisa menggantinya. (b). Penundaan penyaluran pada periode berikutnya apabila kelompok tani belum mampu melunasi pinjaman secara tepat waktu.

\section{Keberlanjutan Finansial}

Keberlanjutan (viabilitas) finansial adalah kondisi pendapatan atau marjin pembiayaan dapat menutup seluruh biaya operasional. LKM-A Gapoktan Sejahtera dapat dikategorikan viable apabila marjin pembiayaan lebih besar dari pada biaya operasional. Biaya operasional meliputi financial loss yaitu

Gambar 1.

\section{Skema Pembiayaan LKM-A Gapoktan Sejahtera}

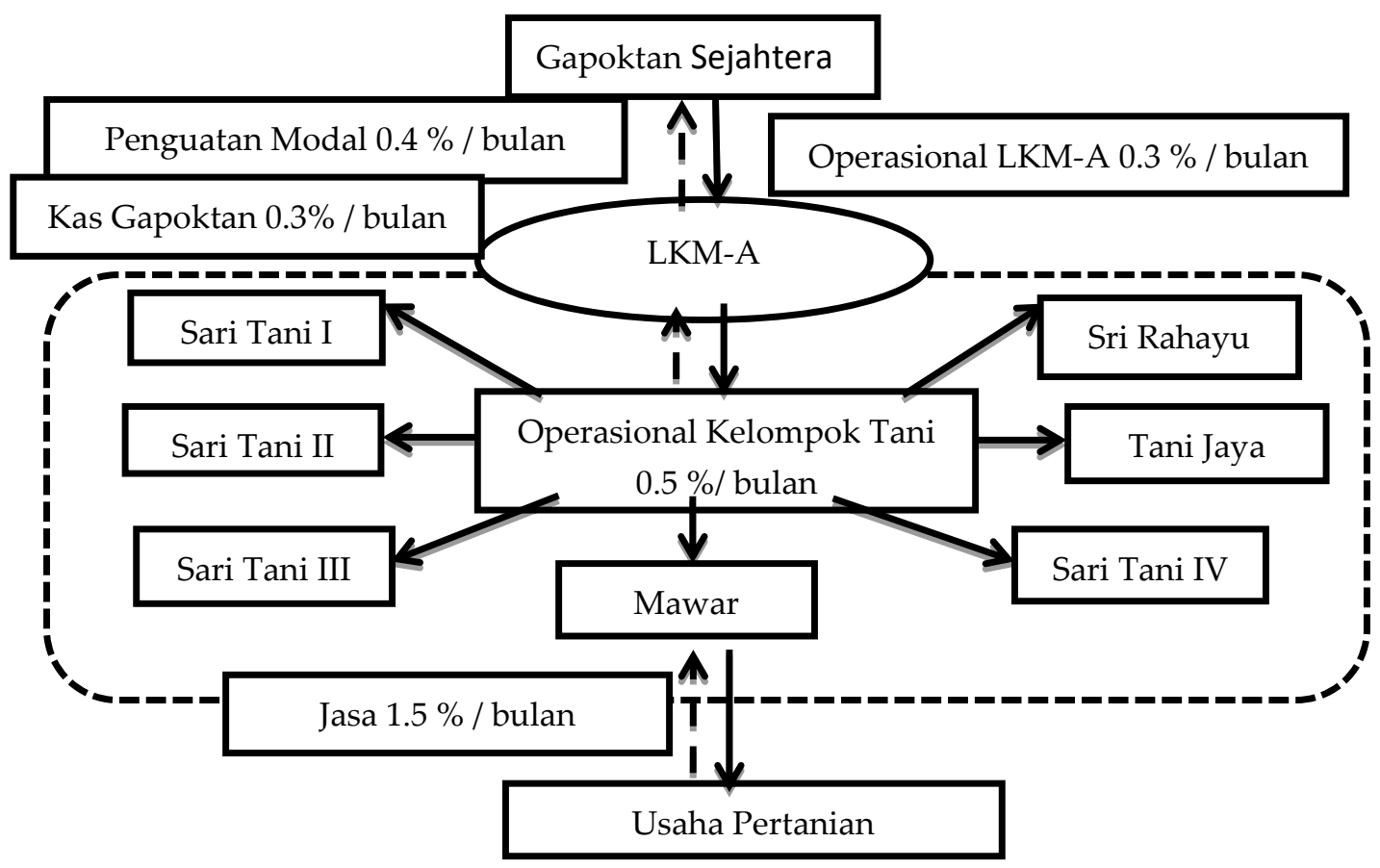


cadangan penghapusan piutang atas tunggakan pembayaran (L), biaya untuk mendapatkan pokok pinjaman (i), serta biaya administasi dan supervisi $(\alpha)$. Berdasarkan informasi laporan keuangan, maka dapat dihitung viabilitas finansial pembiayaan LKM-A Gapoktan Sejahtera selama periode 2011-2014 (Tabel 5). Kondisi finansial dikatakan viable apabila tingkat bunga per unit pinjaman (r) lebih besar dari beban pembiayaan $(\mathrm{i}+\alpha+\mathrm{L}) /(1-\mathrm{L})$.

Dari hasil perhitungan pada Tabel 5, dapat diketahui bahwa LKM-A Gapoktan Sejahtera mencapai kondisi viable setiap tahunnya yaitu mulai tahun 2011-2014. Hal ini menunjukkan bahwa tingkat bunga per unit pinjaman (r) lebih besar dari beban pembiayaan $(\mathrm{i}+\alpha+\mathrm{L}) /$ (1-L). Nilai beban bagi hasil terendah dimiliki LKM-A Gapoktan Sejahtera pada tahun 2013 karena pada tahun tersebut LKM-A Gapoktan Sejahtera mulai membentuk LKM-A dengan sistem pembiayaan satu musim melalui bunga pinjaman yang rendah sebesar $1.5 \%$ disertai persyaratan peminjaman yang mudah melalui kelompok tani, sehingga tidak membebankan bagi hasil.

\section{Keberlanjutan Nasabah atau Anggota}

Keberlanjutan nasabah LKM-A Gapoktan Sejahtera menggunakan persepsi nasabah petani sebagai anggota. Analisis persepsi nasabah petani disesuaikan dengan tujuan program PUAP dan indikator keberhasilan pengelolaan dana PUAP oleh LKM-A dalam kemampuannya menjangkau anggota kelompok tani yang benar-benar memerlukan bantuan penguatan modal untuk kegiatan usahatani. Persepsi petani yang dianalisis dibagi dalam tiga instrumen kelompok, yaitu 1) persepsi nasabah petani terhadap penyaluran dana PUAP, 2) persepsi nasabah petani terhadap pemanfaatan dana PUAP, dan 3) persepsi nasabah petani terhadap pengembalian dana PUAP. Responden penelitian analisis keberlanjutan nasabah ini adalah nasabah LKM-A Gapoktan Sejahtera sebanyak 60 orang dengan menggunakan skor penilaian skala likert 1-5 ( $1=$ sangat tidak penting, $2=$ tidak penting, $3=$ cukup penting, $4=$ penting, $5=$ sangat penting). Hasil keberlanjutan nasabah berdasarkan persepsi anggota ditunjukkan pada tabel 6 .

Penilaian terhadap indikator penyaluran danaPUAPkepadanasabah petanimenggunakan 5 parameter, yaitu; (1) Keterlibatan anggota LKMAdalam pembuatan RUB, (2) Ketersediaan dana PUAP, (3) Kemudahan persyaratan penerima PUAP, (4) Sosialisasi program PUAP kepada anggota, (5) Seleksi calon penerima dana PUAP. Hasil kelima parameter tersebut mempunyai rata-rata nilai 3.95 yang mendekati nilai 4 artinya nasabah petani menilai penting aspek penyaluran PUAP. Penilaian terhadap pengembangan dana PUAP untuk nasabah petani menggunakan 3 parameter, yaitu; (1) Sebagai unit simpan pinjam, (2) Pemahaman terhadap kesesuaian dana yang diterima dengan kebutuhan usaha tani, (3) Pemahaman akan jaminan atau agunan untuk pinjaman

Tabel 5.

Viabilitas Finansial LKM-A Gapoktan Sejahtera

\begin{tabular}{cccccccc}
\hline Tahun & $\mathrm{L}$ & $\mathrm{A}$ & $\mathrm{I}$ & $\begin{array}{c}\text { Hasil Bagi } \\
(\mathrm{i}+\alpha+\mathrm{L}) /(1-\mathrm{L})\end{array}$ & $\mathrm{r}$ & selisih $(6-5)$ & viabilitas \\
\hline 1 & 2 & 3 & 4 & 5 & 6 & 7 & 8 \\
\hline 2011 & 0.003 & 0.006 & 0.05 & 0.059177533 & 0.18 & 0.120822467 & Viable \\
2012 & 0.007 & 0.01 & 0.05 & 0.067472306 & 0.18 & 0.112527694 & Viable \\
2013 & 0.002 & 0.003 & 0.05 & 0.05511022 & 0.18 & 0.12488978 & Viable \\
2014 & 0.002 & 0.004 & 0.05 & 0.056112224 & 0.18 & 0.123887776 & Viable \\
Rata-rata & 0.0035 & 0.00575 & 0.05 & 0.059468071 & 0.18 & 0.120531929 & \\
\hline
\end{tabular}

Sumber : Data Primer (2015) 
dana PUAP. Hasil rata-rata penilaian aspek pemanfaatan dana PUAP menghasilkan nilai 3.63 yang mendekati nilai 4 artinya nasabah petani telah merasakan pemanfaatan dana PUAP untuk modal usahataninya cukup baik. Penilaian terhadap pengembalian dana PUAP menggunakan 3 parameter, yaitu; (1) Ketepatan pengembalian dana PUAP, (2) Perguliran dana PUAP pada kelompok lain, (3) Peningkatan unit usaha. Dari hasil pengembalian dana PUAP mendapatkan nilai rata-rata 3.98 mendekati nilai 4 , artinya nasabah telah memiliki tingkat kepentingan terhadap pengembalian PUAP. Hal ini didukung juga dengan adanya peningkatan akumulasi dana PUAP, terbukti selama 3 tahun berjalan sejak 2011 sampai 2014, LKM-A Sejahtera mampu meningkatkan dana sebesar 115 juta rupiah; tingkat pengembalian pinjaman dana PUAP oleh anggota, telah diantisipasi melalui kelompok tani dengan sistem tanggung renteng, sehingga tingkat pengembalian mencapai 98 persen; dan pengurangan jumlah petani miskin, terbukti dengan adanya dana
PUAP kebutuhan usaha tani tercukupi melalui pembelian saprodi dan penyisihan konsumsi rumah tangga melalui renovasi pembangunan rumah.

\section{Implikasi Pola Pengembangan Co-operative Entrepreneurship LKM-A}

Perumusan implikasi pola pengembangan LKM-A di Kabupaten Lamongan dihadapkan oleh berbagai tantangan, mulai dari yang bersifat kebijakan hingga hal-hal yang bersifat teknis. Hingga saat ini Pemerintah Kabupaten Lamongan belum mengeluarkan peraturan daerah yang secara khusus menangani LKM-A, sehingga pengembangan LKM-A ke depan belum memiliki konsep dan strategi yang jelas. Dalam penelitian ini, perumusan implikasi pola pengembangan LKM-A di Kabupaten Lamongan menggunakan metode pendekatan kewirausahaan koperasi ( $\mathrm{Co}$ operative Entrepreneurship) dengan melibatkan unsur pelaku dan proses.

Tabel 6.

Keberlanjutan nasabah LKM-A Gapoktan Sejahtera

\begin{tabular}{clc}
\hline No & \multicolumn{1}{c}{ Parameter Keberlanjutan Nasabah } & Rata-Rata Nilai \\
\hline A & Aspek penyaluran dana PUAP & \\
1 & Keterlibatan anggota LKMA dalam pembuatan RUB & 3.41 \\
2 & Ketersediaan dana PUAP & 4.25 \\
3 & Kemudahan persyaratan penerima PUAP & 4.13 \\
4 & Sosialisasi program PUAP & 4.00 \\
5 & Seleksi calon penerima PUAP & 3.97 \\
\hline & Total rata-rata (A) & 3.95 \\
\hline B & Aspek Pemanfaatan dana Program PUAP & 4.22 \\
1 & Sebagai unit simpan pinjam & 3.78 \\
2 & Pemahaman terhadap kesesuaian dana yang diterima dengan & \\
& kebutuhan usaha tani & 2.88 \\
\hline 3 & Pemahaman akan jaminan/agunan untuk pinjaman dana PUAP & 3.63 \\
\hline & Total rata-rata (B) & 4.06 \\
\hline C & Aspek pengembalian dana PUAP & 3.56 \\
1 & Ketepatan pengembalian dana PUAP & 4.31 \\
\hline 2 & Perguliran dana PUAP pada kelompok lain & 3.98 \\
\hline
\end{tabular}

Sumber: Data Primer (2015) 
Implikasi pola pengembangan co-operative entrepreneurship difokuskan pertama pada sisi pelaku yaitu pengembangan sumberdaya manusia yang ada dan potensial untuk bentuk menjadi seorang wirakoperasi yaitu melalui unit usaha otonom LKM-A yang mempunyai prinsip koperasi. Sumber daya manusia potensial LKM-A salah satunya melalui Ketua Kelompok tani yang menjadi panutan anggota. Tugas utama wirakoperasi adalah mengambil prakarsa inovatif, artinya berusaha mencari, menemukan, dan memanfaatkan peluang yang ada demi kepentingan bersama. Kewirausahaan dalam koperasi dapat dilakukan oleh anggota, manajer birokrat yang berperan dalam pembangunan koperasi dan katalis, yaitu orang yang peduli terhadap pengembangan koperasi.

Pendekatan kedua dilihat dari sisi proses dengan berdasarkan kedudukan LKM-A dalam gapoktan, yaitu sebagai financial education untuk mendukung unit usaha gapoktan seperti saprodi, produksi, pengolahan, dan pemasaran. LKM-A yang telah berbadan hukum koperasi dengan menerapkan kewirausahaan akan memudahkan pengembangan masing-masing unit usaha gapoktan melalui kerjasama dengan lembaga lain. Berdasarkan hasil wawancara responden, yaitu pejabat Direktorat Pembiayaan Pertanian, Pejabat Dinas Pertanian Kabupaten Lamongan, PMT, Ketua LKM-A dan Dosen Perguruan Tinggi Pertanian, menyatakan bahwa legalitas, kemitraan dan kelembagaan yang kuat merupakan faktor utama dalam keberlanjutan LKM-A. Misalnya untuk mendapatkan pendanaan dari bank, maka pendirian LKM-A perlu berbadan hukum dan melengkapi persyaratan administrasi lainnya. Atau dengan kemitraan dengan berbagai lembaga yang ada, LKMA dapat memperoleh pengetahuan, keterampilan, dan modal. Sedangkan kelembagaan menjadi faktor penentu karena dengan kelembagaan yang kuat, maka LKM-A dapat dengan mudah dikelola, sehingga dapat mendorong tercapainya kemitraan, pendanaan, dan legalitas. Secara keseluruhan, pendanaan dan kemitraan merupakan faktor utama yang perlu diperkuat untuk mencapai tujuan. Pendanaan dapat diperoleh dari lembaga keuangan, bank, atau pemerintah. Sedangkan kemitraan yang perlu dibangun, yaitu dengan lembaga swadaya masyarakat lain, lembaga keuangan, lembaga pendidikan,dan lembaga pelatihan.

Berdasarkangambar2, polapengembangan Co-operative Entrepreneurship LKM-A diawali melalui proses penumbuhan LKM-A. Pemberian dana BLM PUAP oleh Kementerian Pertanian melalui pengajuan Dinas Pertanian Kabupaten dan Propinsi disalurkan langsung melalui Gapoktan desa. Keberlanjutan LKM-A perlu didukung dengan adanya badan hukum. Badan Usaha Milik Petani (BUMP) dibentuk oleh, dari dan untuk petani melalui Gapoktan. BUMP dapat berbentuk koperasi atau badan usaha lainnya sesuai dengan ketentuan peraturan perundangan. Sesuai karakteristik dari BUMP yang dibentuk oleh, dari dan untuk petani melalui Gapoktan maka bentuk badan hukum yang disarankan untuk LKM-A yang melaksanakan prinsip simpan pinjam adalah Koperasi Simpan Pinjam (KSP). Mulai tahun 2015, Kementerian Pertanian memfasilitasi pendampingan untuk pembentukan badan hukum menuju koperasi.

Beberapa prinsip koperasi adalah pengelolaan dilakukan secara demokratis dan untuk kesejahteraan anggota. Sehingga prinsip ini mengarah pada karakter kewirausahaan koperasi, makna kewirausahaan yang dilakukan secara bersama-sama. Dalam pembentukan kewirausahaan koperasi diperlukan pemahaman mengenai materi yang berkaitan sesuai dengan karakter pelaku dan daerahnya. Materi dan kurikulum didasarkan pada Sistem Informasi Pertanian yang disusun atas kerjasama Kementerian Pertanian dan Perguruan Tinggi terkait, melalui kerjasama PPL dan PMT Dinas Pertanian kabupaten sebagai pendampingnya. Integrasi dua lembaga 
tersebut diharapkan mampu merancang metode pelatihan yang komprehensif sesuai dengan perkembangan agribisnis pertanian saat ini sehingga dapat berjalan efektif di lapangan. Keterlibatan perguruan tinggi khususnya perguruan tinggi pertanian dalam program ini juga dapat menjadi bahan pembelajaran bagi mahasiswa dalam pengembangan agribisnis sehingga diharapkan akan lahir dari kalangan mahasiswa yang mampu menjadi wirakoperasi agribisnis di masa mendatang.

Materi dan kurikulum yang disusun selain berasal dari Sistem Informasi Pertanian, juga disesuaikan dengan potensi desa. Potensi desa ini berkaitan dengan kelembagaan Gapoktan yang mewadahi kelompok tani melalui sistem tanggung renteng dan budidaya plant basis yaitu komoditi yang menjadi ciri khas dari daerah bersangkutan yang mempunyai nilai jual di pasar. Materi dan kurikulum ini dibentuk melalui kegiatan sekolah lapang yang terdiri dari pelatihan dan magang. Metode sekolah lapang ditujukan berdasar Sistem Informasi Pertanian dan untuk pengembangan budidaya pertanian berdasar plant basis. Peserta dari sekolah lapang ini adalah Pengurus gapoktan, pengurus LKM-A, dan Ketua Kelompok Tani yang menjadi tokoh sentral dalam pengembangan LKM-A berbasis Co-operative Entrepreneurship. Metode pelatihan dikembangkan berdasarkan metode kelompok. Artinya tokoh sentral Ketua Gapoktan, Ketua LKM-A dan Ketua Kelompok Tani akan mentransfer ilmu yang diperoleh kepada anggotanya. Sehingga lebih efisien biaya dan tempat. Sedangkan metode magang yaitu kegiatan di mana ketua kelompok tani diberikan kesempatan untuk ikut mengelola kelompok tani lain yang sudah berhasil. Diharapkan dengan adanya magang antar kelompok tani ini dapat menjadi referensi dan memotivasi antar kelompok tani khususnya kelompok tani yang belum maju sehingga dapat segera disusun sebuah program pengembangan kelompoktaninya.
Metode pelatihan dan magang dalam kegiatan sekolah lapang ini membagi materi menjadi dua yaitu, materi pokok Human Capital dan Social Capital. Human Capital sebagai materi usaha mempelajari teknik budidaya, teknik pemasaran, dan teknik pembukuan. Social capital sebagai materi organisasi mempelajari teknik kepemimpinan dan teknik kewirausahaan. Dari materi pokok Human Capital dan Social Capital inilah diharapkan ketua Gapoktan, ketua LKM-A, dan Ketua kelompok tani dapat mengembangkan LKM-A berbasis co-operative entrepreneurship. Adapun pola pengembangan wirakoperasi LKM-A Gapoktan Sejahtera dapat dilihat pada Gambar 2.

\section{Kesimpulan}

1. Penumbuhan LKMA padaGapoktanSejahtera mempunyai bobot pemeringkatan skala likert dengan nilai rata-rata di atas 3 dengan kategori "baik" pada tahapan persiapan. Sedangkan pada tahapan pelaksanaan dan persiapan pengembangan LKMA, hasilnya dikategorikan "kurang baik", dilihat dari nilai skala biner kurang dari 1.

2. LKM-A Gapoktan Sejahtera sudah memiliki keberlanjutan kelembagaan, finansial dan anggota. Keberlanjutan kelembagaan didukung oleh manajemen organisasi pembiayaan dan skema pembiayaan selama satu musim tanam. Keberlanjutan finansial dibuktikan melalui tingkat bunga per unit pinjaman lebih besar dari beban pembiayaan. Keberlanjutan anggota melalui efektivitas penyaluran PUAP kepada nasabah.

3. Implikasi pola pengembangan co-operative entrepreneurship menggunakan dua pendekatan yaitu pelaku dan proses. Pendekatan pelaku difokuskan pada pengembangan sumberdaya manusia yang ada dan potensial untuk bentuk menjadi seorang wirakoperasi. Pendekatan kedua dilihat dari sisi proses, yaitu sebagai financial education untuk mendukung 
Gambar 2.

Metode Pola Pengembangan Co-Operative Enterpreunership LKM-A Gapoktan Sejahtera

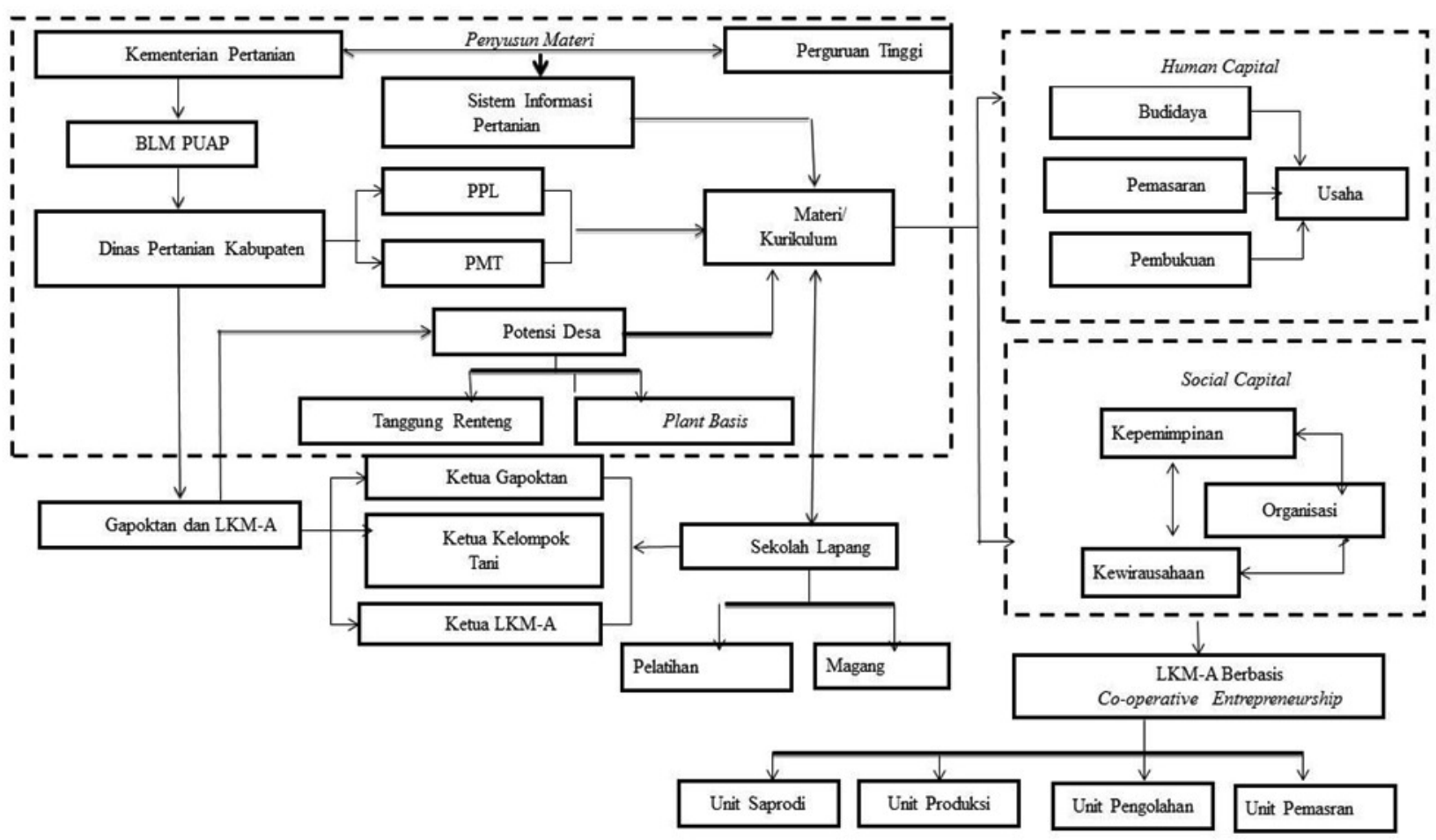

kewirausahaan unit usaha gapoktan seperti saprodi, produksi, pengolahan, dan pemasaran.

\section{Saran}

1. Untuk proses penumbuhan LKM-A Lamongan perlu ditingkatkan peranPenyelia Mitra Tani (PMT) dalam pendampingan administrasi dan pembukuan.

2. Mengembangkan unit otonom LKMA tidak hanya sebagai lembaga peminjaman, tapi juga tabungan dan memperoleh pinjaman dana dari lembaga yang menetapkan bagi hasil yang lebih rendah untuk keberlanjutan LKM-A.

3. Mengembangkan proses penumbuhan bisnis dan membangun jiwa kewirausahaan dengan membangun linkage dengan sektor perbankanuntuk pinjaman modal, pemasaran melalui mitra unit promosi Kabupaten, pengolahan hasil pertanian melalui kerjasama dengan dinas UKM kabupaten, perguruan tinggi pertanian dalam hal pelatihan dan penyusunan kurikulum, dengan tujuan untuk meningkatkan peran co-operative entrepreneurship LKM-A.

\section{Daftar Pustaka}

Baga LM. (2011). Profil dan Peran Wirakoperasi dalam Pengembangan Agribisnis. Prosiding Makalah Seminar Penelitian Unggulan Departemen Agribisnis IPB. (Online). (http://repository.ipb.ac.id/bitstream/ handle/123456789/65350/11, diakses 10 Juni 2015).

Baga LM. (2015). Co-operative Entrepreneurs and Agribussines Development. Bogor (ID): IPB Press.

Badan Pusat Statistik. (2014). Luas Panen Tanaman Padi, Jagung, Kedelai Provinsi di Indonesia Tahun 2014. (Online). (www.bps. go.id, diakses 28 Mei 2015)

Direktorat Pembiayaan Pertanian, Kementerian Pertanian. (2014). Pedoman Pengembangan 
LKM-A Gapoktan PUAP. Jakarta: Kementan.

Herbel D, Mariagrazia D, Ferrier C. (2015). The Role of the Social and Organitational Capital in Agricultural Cooperatives' Development Practical Lessons from the CUMA Movement. Journal of Co-operatives and Management (Online), Volume 3, Issue 1, p.24-31, June 2015 (www.elsevier.com/ locate/jcom., diakses 27 Agustus 2015)

Kaur, Prabhjot. (2014). Outreach and Sustainability of Microfinance Institutions in India in Pre and Post Andhra Pradesh Microfinance Crisis in Context of South Asia. Global Journal of Finance and Management. Vol. 6 No. 6.

Kementerian Pertanian. (2012). Petunjuk Teknis Pemeringkatan (Rating) Gapoktan PUAP menuju LKM-A.Jakarta: Kementerian Pertanian.

Kementerian Pertanian. (2014). Pedoman Umum Pengembangan Usaha Agribisnis Perdesaan. Jakarta: Kementerian Pertanian.

Khandker, S.R, B. Khalily and Z. Khan. (1995). Grameen Bank: Performance and Suistainability. Journal of World Bank 306. Washington DC: The World Bank.
McDonnell, Macknight and Donnelly. (2012). Co-operative Entrepreneurship: Co-operate for Growth. Scottish Government and the Economic and Social Research Council.

Setyarini P. (2008). Analisis Kinerja Lembaga Keuangan Mikro Swamitra Amina dengan Pendekatan Balanced Scoreced (Studi Kasus di Kabupaten Bantul, Yogyakarta). Tesis. Bogor: Institut Pertanian Bogor.

Saragih. (2015). Suara Agribisnis 2, Kumpulan Pemikiran Bungaran Saragih. Bogor: Gaung Persada Pr.

Suhartono, Iman. (2011). Strategi Pengembangan Koperasi Berorientasi Bisnis. Jurnal Among Makarti, Vol. 4 No. 7 Edisi Juli.

Syukur M. (2002). Analisis Keberlanjutan dan Perilaku Ekonomi Peserta Skim Kredit Rumah Tangga Miskin. Disertasi. Bogor: Institut Pertanian Bogor.

Yunus. (2008). Turning Beggars Into Entrepreneurs. The Center for the Study of Democratic Institutions.

Zeller and Meyyer. (2002). The Triangle of Microfinance: Financial Sustainability, Outreach, and Impact. International Food Policy Research Institute. Baltimore and London: The Johns Hopkins Universit. 